\title{
Renewable Energy Perception by Rural Residents of a Peripheral EU Region
}

\author{
Ozgur Kaya ${ }^{1}$, Wojciech J. Florkowski ${ }^{2, *(\mathbb{D})}$, Anna Us ${ }^{3}$ and Anna M. Klepacka ${ }^{4}$ \\ 1 Department of Economics, School of Business Administration, American University of Sharjah, Sharjah, \\ P.O. Box 26666, UAE; okaya@aus.edu \\ 2 Department of Agricultural and Applied Economics, University of Georgia, Griffin, GA 30223-1797, USA \\ 3 Department of Agricultural and Applied Economics, Pope John Paul II State School of Higher Education, ul. \\ Sidorska 95/97, 21-500 Biala Podlaska, Poland; usanna@op.pl \\ 4 Faculty of Production Engineering, Warsaw University of Life Sciences-SGGW, ul. Nowoursynowska 164, \\ 02-787 Warsaw, Poland; anna_klepacka@sggw.pl \\ * Correspondence: wojciech@uga.edu; Tel.: +1-770-228-7233
}

Received: 1 March 2019; Accepted: 1 April 2019; Published: 8 April 2019

\begin{abstract}
Renewable energy (RE) sources are often locally available and have the potential to lessen the rural dependence on the national power grid, reducing disruptions in power supplies and the heavy dependence on coal combustion. Poland faces an EU mandate of a 15\% share of renewables in energy generation by 2020. However, the installations intended to supply several types of RE encountered local opposition, forcing a cancellation of the planned investments and stressing a need for understanding rural residents' attitudes towards RE in general. Using survey data, this paper examines the perception of RE importance among rural residents in eastern Poland. The specified empirical relationship includes the sociodemographic and economic characteristics of residents. Perceptions of the links between health and specific sources of environmental pollution and actions demonstrating energy-saving behavior serve as explanatory variables. The performance of the estimated logit equation was rigorously tested. The probability of attaching importance to RE by rural residents increases most if a respondent displayed an energy-saving behavior, has certain demographic characteristics, and links health to environmental pollution caused by coal combustion. The graphic depiction of the effects of selected variables succinctly communicates possible future programs aimed at strengthening the rural population support of RE.
\end{abstract}

Keywords: renewable energy; rural area; survey; logit; probability change; probability change prediction

\section{Introduction}

Renewable energy is energy produced from sources that do not deplete and that are replenished in a human lifetime. It is considered a potentially new source for jobs and rural development in participating countries. The European Union (EU) has been at the forefront of global renewable energy deployment. The implementation of long-term targets and supporting policy measures in the EU resulted in increased renewable energy consumption across this region from an $8.5 \%$ share in 2004 to $17.5 \%$ in 2017 on a path to the 2020 target of $20 \%$. The quantity of renewable energy produced within the EU increased overall by $64 \%$ between 2007 and 2017, equivalent to an average increase of $5.1 \%$ per year. This increase has been mainly driven by the legally binding targets for increasing the share of energy from renewable sources. Among the European Commission (EC) mandated targets is the minimum share of $15 \%$ of energy generated from renewables by 2020 [1] that has been recently revised to $32 \%$ for the EU as a whole by 2030 [2]. Increasing the use of renewable energy could reduce the EU's 
dependence on fossil fuels and imported energy and can contribute to the security of its energy supply. Several EU and national funding programs incentivize the production and use of renewable energy including the European Agricultural Fund for Rural Development (EAFRD) (2018) [3].

Renewable energy utilization is an element of a sustainable growth strategy. Many renewable energy sources are easily and locally accessible and have the potential to lessen the rural area dependence on the national power grid through local energy generation and to improve energy security [4]. Power supply disruptions are more frequent and last longer in rural than urban areas in Poland [5,6]. Rural residents are also large users of fossil fuels, especially coal, used to heat space and water in the predominantly single-family housing in Polish villages. Burning coal produces particulate matter and emits greenhouse gases that negatively affect human health [7] and climate [8], while polluting the surface water, soil, and air. To counter the negative effects of fossil fuel use, the Polish government implemented policies consistent with the objectives of the energy, climate, and environmental policies adopted by the EC.

The expansion of renewable energy generation is consistent with the principle of sustainable development as the path of the country's development named in the Constitution of the Republic of Poland passed by referendum in 1997. Renewable energy development involves the construction of various installations, and rural areas are a primary location because of the availability of land (or surface area), technical feasibility, and the presence of suitable feedstock. However, winning public support for some projects proves challenging, suggesting that public attitudes vary with regard to various forms of generating renewable energy. As some investors in renewable energy facilities learned in Poland, the decisive factor is the perception of such facilities among local rural residents. For example, a number of proposed windmill constructions faced strong local protests that resulted in investors withdrawing from the area [9]. Some protests involved the opposition of biogas plant construction [10]. Knowledge of rural residents' attitudes is important in anticipating the acceptance of specific projects despite all advantages in terms of energy supply improvement and benign environmental effects.

This paper examines the importance that rural residents attach to renewable energy. Since renewable energy projects have impacts on landscape, wildlife, air pollution, electricity prices, and job opportunities [11], there may be a difference in terms of the preferences of rural and urban residents for renewable energy developments. Bergmann et al. [12] show that, in the case of Scotland, rural people value, among others, a reduction in air pollution due to renewable energy use more than their urban counterparts do. Bidwell [13] stresses the pivotal role of attitudes towards renewable energy and suggests more participation of local residents in the process of locating renewable energy generating facilities. The geographic focus of this paper is on rural areas of Lubelskie Voivodship in Poland. The area has some of the most favorable conditions regarding the potential use of solar energy in the country and plentiful biomass supply, while its low population density ( $30 \%$ below national average) and rural character makes it prone to energy supply disruptions. It is one of the least developed areas in the European Union (EU) with per capita incomes nearly 30\% lower than the national average [14]. The remote location of settlements suggests that the region could benefit from micro-installations, utilizing renewable energy [15] and reducing the use of coal as the primary source of energy in rural households. This study identifies rural resident characteristics, their opinions about renewable energy attributes and environmental quality as it relates to their personal well-being, and the perceived importance of renewable energy in general. Learning about factors shaping rural resident attitudes towards renewable energy streamlines efforts to expand renewable energy utilization enabled by the EU cohesion funds intended for improving rural life quality, while contributing to the EU climate and environmental policy.

\section{Attitudes towards Renewable Energy}

In 2014, Eurobarometer inquired about the importance of the national targets set by governments to increase the amount of renewable energy by 2030. A summary of the survey results showed $90 \%$ of the EU population believed it to be important for national governments to set targets to 
increase the renewables with almost half (49\%) saying it is "very important" and $41 \%$ saying that it is "fairly important". In Poland, 33\% of the population thought that renewable energy targets of their government are "very important", whereas another 55\% thought that such targets were "fairly important", a relatively lower level of importance than the EU average [16]. More recently, the Renewable Energies Agency (known as AEE) of Germany reported that renewable energy enjoys strong support based on surveys from a number of countries, including Japan, Canada, Australia, New Zealand, USA, Germany, France, the United Kingdom, and Poland [17]. The AEE also reported that countries with a relatively low development of renewable energy (e.g., Japan, the USA, and Australia) as well as countries with a high development (e.g., Germany, Sweden, and Denmark) all show high acceptance levels of renewable energy. The highest degree of renewable energy acceptance was shown in Germany with $93 \%$, closely followed by France (89\%) and Japan (88\%). In an earlier survey in Poland, more than $80 \%$ of the participants thought that renewable energy influences the technological progress in Poland positively, more than $90 \%$ of the participants thought renewable energy has positive environmental effects, and $72 \%$ of the participants believed renewables were conducive to the security of the energy supply [18]. Positive environmental effects due to renewable energy use were also mentioned in another study of Polish residents [19].

However, there is a clear distinction between the general attitudes favoring government involvement in setting renewable energy targets or renewable energy use in general and the specific forms of renewable energy. For example, public support for solar energy has been generally strong. Support for solar energy is $87 \%$ in the UK [20] and 85\% in Switzerland [21]. In the case of the US, half of the respondents considered solar power as the most important energy source for America's future, with solar as the top choice across all major demographics [22], and 79\% of Americans were in favor of increasing the use of solar energy [23]. The survey done by Zogby Analytics for SolarCity [22] in the US showed that $87 \%$ of Americans considered renewables to be important for the future of energy and that half the respondents considered solar energy to be of prime importance. Still, some renewable energy projects meet with opposition reflecting the NIMBY ("not-in-my-backyard") phenomenon. A study from Switzerland showed greater positive attitudes towards wind energy in general than locating windmills near the respondent's location [24].

The attitudes of Polish villagers are in line with the reactions of residents in other countries and vary towards the specific sources of renewable energy. Based on a survey of 200 residents in Poland, Eiser et al. [25] found that a community affected by proposals for nearby wind farms were, on average, less favorable towards wind energy development, were less convinced that wind energy would help mitigate climate change, and were more inclined to believe it might have negative impacts in Poland. Gielnik and Rosicki [26] named several effects of windmills influencing attitudes and creating social barriers in wind energy utilization. Based on another survey of 1169 respondents, Mroczek and Kurpas [27] analyzed the social attitudes of Poles toward wind power and other renewable energy sources. They found that the majority of the respondents declared their support for wind power and other renewables. A study of rural residents in the Lubelskie Voivodship found unfavorable attitudes towards locating a biogas plant in the respondent village but not so much in another county [28], resembling NIMBY attitudes. A study of NIMBY attitudes among rural residents in Poland with regard to three renewable energy projects conflicts with an identified opposition to biogas and windmill location [29].

An integrated system, which combines multiple renewable energy sources, has been advocated as a way to increase the efficiency and reliability of renewable energy supplies. Examples of such systems include the use of solar energy and biogas [30]. The technical feasibility and effective investment in such systems pose a challenge arising from specific country-conditions that encompass not only the accessibility of various types of renewable energy but also the existing energy supply infrastructure and regulatory regimes and financing. For example, the ubiquitous but intermittent presence of solar energy, which enables the use of an integrated system consisting of passive solar and PV panels, can be supplemented by a biogas plant. The latter enhances the reliability of energy production only if 
the locality provides a steady and adequate supply of substrata to maintain fermentation. Such an integrated system presupposes the availability of adequate surface with uncontested property rights. In countries lacking a technical infrastructure enabling the distribution of electricity across all or some regions, the construction of a self-contained integrated system could offer not only a technically but also an economically feasible solution [31,32].

In the EU, including Poland, the existing grid covers all member countries. The presence of an energy-supplying technical infrastructure is also associated with the regulatory regime, standardization, monitoring, and inspection that force any renewable energy-generating facilities to perform within the existing system. The key role of the regulatory regime is well-illustrated in the case of Poland, where an investment in household-owned photovoltaic (PV) equipment connected to the grid was not permitted until the passing of the law in summer of 2017 [33]. Prior to enacting the law, households invested in solar panels used to heat water. Poland also enacted a broad plan of establishing a biogas plant in every county [34]. However, the plan has been implemented slowly because of the need to assure the supply of local substrata and only with substantial financial support from the EU cohesion funds. The law regulates the capacity of renewable energy facilities that complicate the construction of integrated systems. The recent change in regulations affecting construction imposes strict requirements on the use of multiple types of renewable energy and in the design of new buildings. The integrated system combines the use of PV panels and a heat pump or geothermal installation supported by the use of extensive insulation and high efficiency windows. The availability of subsidies for private individual investors in using renewable energy has been of major importance in Poland [35] because the initial cost is relatively high, even in the case of solar panels used to heat water.

Public acceptance is considered an important issue shaping the widespread implementation of renewable energy technologies and the achievement of energy policy targets [36-38]. Knowledge about general attitudes helps to tailor specific education messages, increasing local awareness on a particular type of renewable energy abundant in a given area because various sources of renewable energy are unequally distributed across Poland, making some technology more suitable in a specific region [39]. Learning about Lubelskie Voivodship rural resident attitudes in general provides insights into major universal factors, likely determining the attitudes of rural populations in other regions and allowing for public participation in the discussion of specific benefits, not only the potentially negative aspects stemming from renewable energy generation. A better understanding of renewable energy supports the enactment of policies addressing energy, environmental, and climate problems reflected in the EU renewable energy mandate. Lubelskie Voivodship is an ideal area for this study because of the opportunities to use solar energy, wood biomass, biogas from agricultural waste, biofuel feedstock, and wind energy.

\section{Materials and Methods}

\subsection{The Modeling Approach}

Rural residents displayed a range of attitudes towards specific types of renewable energy ranging from opposition to the construction of windmills or biogas plants to favorable opinions about solar panels. To capture a range of attitudes, this study allowed a respondent to assign a value between 1 and 10 to indicate the importance they attached to renewable energy. The selected option yields itself to modification in empirical research. It allows defining the variable reflecting the importance attached to renewable energy by choosing the threshold value. In the current study, the selected options were grouped into two categories, where 6 was the threshold value. Values of less than 6 were considered as indicating that renewable energy was unimportant and values 6 or higher implied the opposite.

To know whether an issue, attribute, or product is important typically does not pose difficulties for an individual to decide, especially if it pertains to an everyday situation. Public opinion surveys commonly ask respondents if a particular feature or outcome is important. The straightforward question probes for the importance attached to an item or issue. 
The observed response has a binary outcome that is easily coded, creating a binary variable (a variable that assumes only two values, zero or one). Typically, the indicated importance is coded as 1 ; otherwise, it is coded as 0 . Once coded, the responses can be applied in the modeling that explains the observed outcome in the context of various descriptors.

Let $y^{*}$ be an unobserved, or latent, variable, determined by

$$
\begin{gathered}
y^{*}=x \beta+\varepsilon, \\
y=1 \text { if } y^{*}>0, \\
y=0 \text { if } y^{*} \leq 0,
\end{gathered}
$$

where $x$ is the explanatory variable vector, $\beta$ is the coefficient vector, and $\varepsilon$ is the random error term.

Since the dependent variable is binary, a linear probability model can be used to estimate the model. Using the ordinary least squares (OLS) method to estimate a model with a binary dependent variable is known as creating a linear probability model (LPM). However, a linear probability model has some drawbacks. The two most important disadvantages are that the fitted probabilities can be less than zero or greater than one and that the partial effect of any explanatory variable is constant. These limitations of the LPM can be overcome by using a more sophisticated binary response model [40]. In a binary response model, we estimate the following population regression model

$$
P\left(Y=1 / X_{i}\right)=\phi\left(\beta_{0}+\beta_{i} X_{i}\right)
$$

where $X$ represents the full set of explanatory variables. Various nonlinear functions have been suggested for estimating the function $\phi$ to assure the probabilities fall between zero and one. However, the most commonly used methods are the probit or logit models.

Probit and logit regression are nonlinear regression models specifically designed for binary dependent variables. Because a regression with a binary dependent variable $Y$ models the probability that $Y=1$, it adopts a nonlinear formulation that forces the predicted values to be between 0 and 1 . Because cumulative distribution functions (CDFs) produce probabilities between 0 and 1 , they are used in logit and probit regressions. Probit regression models use the standard normal CDF. Logit regression models are similar to probit regression models except that the cumulative standard normal distribution function $\phi$ is replaced by the cumulative standard logistic distribution function [41]. As with the probit, the logit coefficients are best interpreted by computing predicted probabilities and differences in predicted probabilities.

The coefficients of the logit model are estimated by the maximum likelihood. The maximum likelihood estimator is consistent and normally distributed in large samples, so t-statistics and confidence intervals for the coefficients can be constructed in the usual way [41].

There may be practical reasons for favoring logit or probit in some cases, but it is difficult to justify the choice on theoretical grounds [42]. Therefore, the choice is based on the Akaike's Information Criterion (AIC) and Bayesian Information Criterion (BIC).

In a statistical analysis, the logit model uses maximum likelihood estimations from an iterative process. When analyzing data with a logistic regression, an equivalent statistic to $R^{2}$ does not exist. Accordingly, to evaluate the goodness-of-fit of logistic models, several formulas of a pseudo $R^{2}$ have been developed. The name "pseudo" $R^{2}$ (as compared to $R^{2}$ as a measure of a fit when using the OLS technique) implies a similar scale, ranging from 0 to 1 , with higher values indicating a better model fit, but their interpretation differs from an OLS $R^{2}$. The current study reports the McFadden's $R^{2}$, a measure most commonly used in empirical studies. The logistic regression is estimated by 
maximizing the likelihood function. Thus, if $L_{0}$ is the value of the likelihood function for a model without predictors and $L_{M}$ is the likelihood for the model being estimated, McFadden's $R^{2}$ is defined as

$$
R_{M c F}^{2}=1-\frac{\ln \left(L_{M}\right)}{\ln \left(L_{0}\right)}
$$

where $\ln ($.$) is the natural logarithm [43]. The log likelihood of the intercept model with no predictors$ is treated as a total sum of squares, and the log likelihood of the full model is treated as the residual sum of squares. Thus, the ratio of the likelihoods suggests the level of improvement over the intercept model offered by the full model. A likelihood falls between 0 and 1 , so the log of a likelihood is less than or equal to zero. If a model has a very low likelihood, then the log of the likelihood will have a larger magnitude than the log of a more likely model. Thus, a small ratio of log likelihoods indicates that the full model fits better than the intercept model [44]. Comparing two models applying the same dataset, the McFadden's $R^{2}$ would be higher for the model with the greater likelihood [45].

Additionally, this study reports Tjur's coefficient of discrimination (i.e., Tjur's $R^{2}$ ) which is found to be more intuitive [46]. Unlike the pseudo $R^{2}$ s such as the Cox-Snell or the McFadden, Tjur's $R^{2}$ is not based on the quantity being maximized, that is, the likelihood function. Thus, it compares the predictive power for models generating predictions using very different methods. Tjur's $R^{2}$ has a lot of intuitive appeal; its upper bound is 1.0, it is closely related to $R^{2}$ definitions used to measure the robustness of linear models, and it is easy to calculate. For each of the two categories of the dependent variable, the mean of the predicted probabilities of an event is calculated and then the difference between those two means is taken. Thus, if a model makes good predictions, the cases with events should have high predicted values and the cases without events should have low predicted values [43].

\subsection{Data}

The study applies the survey data collected from residents of 13 villages in the Lubelskie Voivodship in Poland. The villages are located in the northern and southern areas of the voivodship. After the pilot test, which did not reveal difficulties in understanding the questions, printed copies of the survey instruments were delivered to randomly selected residents. The questionnaire was self-administered by a respondent, and the completed questionnaires were collected by an enumerator within a few days. The survey began on July 1 and ended on 12 August 2013. The final sample includes 200 returned questionnaires.

The structured questionnaire included several parts focusing on various issues related to renewable energy. A question probing for attitudes towards renewable energy offered a binary choice response, i.e., yes/no, which has been modeled as a decision and estimated using a latent variable approach in empirical studies. Another question asked about the importance of energy saving to capture attitudes consistent with conservation behavior. By indicating the importance of energy saving along the five-step scale, rural respondents demonstrated how important the overall issue of energy is to them. Although modern life is dependent on energy in virtually all its aspects, it is worthwhile to know the degree of importance attached in rural communities.

A set of questions pertained to the displayed behavior consistent with energy-saving attitudes such as the purchase of energy-saving home appliances. Ownership of washing machines has undergone the most dramatic change in rural households over the last two decades. Some rural households did not have a washing machine, while many were replacing the old, nonautomated models with automatic models. In 1994, about $35 \%$ of rural households reported having an automatic washer, nearly $77 \%$ in 2008 [47], and $88.6 \%$ in 2013 [48]. The replaced washing machines must be more energy efficient because of existing EU regulations, and energy savings motivate rural buyers. Dwelling renovations also demonstrate energy-saving attitudes with potential links to renewable energy importance. Energy-efficient renovations involve limited cost energy efficiency measures such as an external window retrofit undertaken by many rural households. Since the majority of single-family dwellings in rural areas were constructed before the modern construction technologies 
recently became available in Poland, a window replacement was considered in one of the questions. Modern windows reduce the energy demand and dependency on coal to heat space.

An additional set of questions focused on the importance of attributes expected to be related to renewable energy. The questions applied a five-step scale to indicate the importance of a specific attribute ranging from 1, not important at all, to 5, very important (the middle step was a neutral view of the attribute's importance). The questions asked about the importance of statements regarding renewable energy supply reliability, safety, and cost as compared to conventional energy sources. Renewable energy could improve the resilience of rural households to the disruption of energy supplies and was viewed as an important aspect in studies of public attitudes [18]. The safety of renewable energy is expected but is not necessarily obvious to rural residents seeing windmill towers or biogas tanks in their area. The cost of renewable energy is a pertinent attribute to rural households, which spend more on energy purchases than urban households in Poland [49], have to absorb transportation costs of coal, and must deal with the disposal of coal ashes.

Four other questions also applied a five-step scale to solicit respondent opinions about the health effects of selected forms of environmental pollution, i.e., air, soil, surface water, and ground water pollution. Air pollution in rural areas is subject to infrequent monitoring, but the common burning of coal affects local air quality, especially by emitting particulate matter. A study in the capital city of Lubelskie Voivodship revealed that emissions from residential coal burning impact outdoor air quality [50], and since rural areas use more coal, similar pollution levels likely occur there. Village residents are exposed to smoke and its contents because they lack access to piped heat or gas common in urban areas. Low capacity residential heating units, especially when using low-grade coal as a fuel, have been associated with mercury emissions [51], exposing rural residents to toxic contaminants. Soil pollution is a familiar issue to rural residents who are farmers or have family members who farm. The surface water pollution results from rural runoff (e.g., livestock presence) and human activity. Runoff from rain and snow melt polluted with fecal matter contributes to the microbiological contamination of surface water, and a study of the Wieprz River that flows through the area of this study revealed the presence of virus particles throughout the year [52]. Additionally, particulate matter from coal combustion is deposited on surface water. Although some forms of pollution can be visually assessed, other forms cannot. The pollution of groundwater is a concern to rural households as that service has become common in Lubelskie Voivodship in recent years [34].

The respondents were also asked to share their demographic and socioeconomic information commonly requested in the national census. The collected information included age, gender, marital status, number of household members, employment status, and monthly household income. All questions probing for information about income and sociodemographic characteristics of the respondent and the household consisted of the same categories as used in the national census in 2010.

\section{Results}

\subsection{Survey Results}

About $52 \%$ of the respondents were female (Table 1), which closely resembles the national average, and $73 \%$ of the respondents were married. The average household consists of 3.7 persons and was larger than the national average, but households in rural areas tend to be multigenerational. About $44 \%$ of the respondents work full-time outside agriculture, while $29 \%$ were farmers. The remaining $25 \%$ were part-time workers, pensioners, disabled, or students. The respondents' ages ranged from 26 to 85 years. All of the respondents had formal education, and 33\% received a university degree or some college education. The monthly income reported by respondents ranged from less than 1000 zlotys (about $\$ 265.20$ at $\$ 1=3.7708$ zloty on 1 July 2015 [53]) to greater than 4000 zlotys with a mean of 2000 zlotys per month. 
Table 1. The selected descriptive statistics of the dependent and explanatory variables used in the estimation.

\begin{tabular}{|c|c|c|c|c|c|}
\hline Variable Name & Obs & Mean & Std. Dev. & Min & Max \\
\hline \multicolumn{6}{|l|}{ Dependent variable } \\
\hline $\begin{array}{l}\text { Renewable energy is important } \\
\text { Explanatory variables }\end{array}$ & 194 & 0.76 & 0.43 & 0 & 1 \\
\hline Saving energy is important ${ }^{a}$ & 194 & 4.40 & 0.94 & 1 & 5 \\
\hline Purchased a washing machine & 194 & 0.83 & 0.38 & 0 & 1 \\
\hline $\begin{array}{l}\text { Purchased new windows for } \\
\text { apt/house }\end{array}$ & 194 & 0.88 & 0.33 & 0 & 1 \\
\hline $\begin{array}{l}\text { Importance of renewable energy } \\
\text { being safe }^{\text {a }}\end{array}$ & 194 & 4.63 & 0.69 & 1 & 5 \\
\hline $\begin{array}{l}\text { Importance of renewable energy } \\
\text { being reliably supplied without } \\
\text { disruption }^{\text {a }}\end{array}$ & 194 & 4.59 & 0.68 & 1 & 5 \\
\hline $\begin{array}{l}\text { Importance of renewable energy } \\
\text { being cheaper than from conventional } \\
\text { source }^{\text {a }}\end{array}$ & 194 & 4.54 & 0.76 & 1 & 5 \\
\hline $\begin{array}{l}\text { Think that own health is affected by } \\
\text { air pollution a }\end{array}$ & 194 & 4.25 & 0.71 & 2 & 5 \\
\hline $\begin{array}{l}\text { Think that own health is affected by } \\
\text { soil pollution a }\end{array}$ & 194 & 4.35 & 0.74 & 2 & 5 \\
\hline $\begin{array}{l}\text { Think that own health is affected by } \\
\text { surface water pollution }\end{array}$ & 194 & 3.36 & 0.95 & 1 & 5 \\
\hline $\begin{array}{l}\text { Think that own health is affected by } \\
\text { groundwater pollution a }\end{array}$ & 194 & 4.22 & 0.73 & 2 & 5 \\
\hline Gender $(1=$ female $)$ & 194 & 0.52 & 0.50 & 0 & 1 \\
\hline Marital status $(1=$ married $)$ & 194 & 0.73 & 0.45 & 0 & 1 \\
\hline $\begin{array}{l}\text { Number of household members (inc. } \\
\text { respondent) }\end{array}$ & 194 & 3.71 & 1.07 & 1 & 5 \\
\hline Education $(1=$ more than high school $)$ & 194 & 0.33 & 0.47 & 0 & 1 \\
\hline Monthly income & 194 & 3.93 & 1.56 & 1 & 8 \\
\hline Farmer ( 1 = farmer $)$ & 194 & 0.29 & 0.45 & 0 & 1 \\
\hline
\end{tabular}

a Five-step scale: 1 = very unimportant; 2 = unimportant; 3 = neither important nor unimportant; 4 = important; and $5=$ very important. In some options, none of the respondents chose "very unimportant" as the answer.

The respondents seemed to be proactive in terms of having energy-saving home appliances. A substantial number $(83 \%)$ purchased a washing machine during the two and a half years (between January 2011 and June 2013) preceding the survey (Table 1). An interest in energy savings is also responsible for $88 \%$ of respondents changing their windows for new ones. A typical new window has an isolated frame and double-pane, some with additional features that lower the potential heat loss.

Expectations regarding renewable energy are high. Respondents think that it is important that renewable energy is safe, supplied without disruptions, and less expensive than from conventional sources (Table 1). The safety of renewable energy is comparable to energy supplied from conventional sources and often safer. For example, solar panels are very safe and can be installed on the roof of a rural residence, can help to lower emissions from burning coal, and can save the task of handling ashes. The disruption of energy supply can be prevented by linking the renewable energy source with the existing grid. Some sources of renewable energy, for example, solar panels, can meet expectations regarding the cost of energy with the help of a program subsidizing the initial purchase and installation.

The respondents are aware of the link between the pollution of various resources and personal health (Table 1). They are least concerned about the surface water pollution (score 3.36 on a scale 1-5), which may reflect the opinion that using such water is optional. Air pollution, however, affects everybody and is a biological necessity. The average score of perceiving it as important is 4.25 . The highest concerns are expressed about the link between soil pollution and personal health (4.35) and 
possibly reflects that a number of respondents are from farm households engaged in food production. Many rural households also have the opportunity to raise vegetables and fruits, making them aware of the link between soil and the wholesomeness of crops. The respondents also expressed concerns about the subsurface water pollution, most likely associating such a pollution with the quality of drinking water available to them.

All respondents were asked how important renewable energy is to them. Their responses were categorized from 1 to 10, where 1 represented least important and 10 represented the most. However, the very few observations in some categories justified the adaptation of this variable as a binary variable where the responses coded up to 6 on the scale were classified as not important and those above 6 as important. To accommodate the sample design with a dichotomous outcome variable, this study utilizes a dichotomous outcome variable model.

\subsection{Results of Empirical Analysis}

The likelihood ratio chi-square of 89.28 ( $p$-value of 0.0000 ) indicates that, overall, the model fits the data well. The pseudo $R^{2}(0.42)$ and Tjur's $R^{2}(0.47)$ have similar values. The empirical model performs very well in terms of its ability to predict correct outcomes; the percentage of correct predictions is $89.18 \%$.

The regression coefficients indicate positive or negative effects on the response variable, i.e., the view that renewable energy is important. Table 2 shows the odds ratios (OR), the marginal effects, and the corresponding $z$-statistics of the marginal effects. The odds ratios, where the coefficients are the effect of a unit change in an explanatory variable in the predicted odds ratio while the other variables in the model are held constant, carry more practical information than the logistic slope coefficients. Odds greater than 1 suggest that the event is more likely to happen than not, and if the odds are less than 1 , the opposite is true. The interpretation of the listed coefficients is not intuitive or as straightforward as the interpretations of coefficients in a linear regression. However, the interpretation of the individual regression coefficients is as follows: a coefficient greater than 1 means that a one-unit increase in the predictor leads to an increase in the odds of renewable energy being important. The opposite is true if a coefficient is less than 1-a one-unit increase in the predictor leads to a decrease in the odds of renewable energy being important.

Among the socioeconomic and demographic variables, positive effects are statistically confirmed with regard to gender, marital status, education level, and income (Table 2). Females and married respondents are respectively 2.94 and 4.49 times more likely to view renewable energy as important compared to male and unmarried respondents. Table 2 also reports the associated average marginal effects of each predictor on the probability of a positive outcome. The average marginal effect for categorical variables shows how $P(Y=1)$ changes as the categorical variable changes from 0 to 1 after controlling for the other variables in the model, and it may be more intuitive to interpret these coefficients. Accordingly, the average marginal effect in Table 2 shows that the probability of believing in the importance of renewable energy increases by $10 \%$ for females and $15 \%$ for married respondents. Respondents with a higher income $(\mathrm{OR}=1.59)$ and an education level above high school $(\mathrm{OR}=3.08)$ are also more likely to view renewable energy as important. The probability of believing in the importance of renewable energy increases by $11 \%$ for highly educated respondents and $4 \%$ for a one-unit increase in the income level of the respondent. Additionally, farmers are 2.77 times more likely (a 10\% probability increase) to think that renewable energy is important compared to other professions. However, the probability of believing in the importance of renewable energy decreases by $5 \%$ as the household size of the respondent increases. 
Table 2. The results of the logit estimation of equation modeling the perceived importance of renewable energy.

\begin{tabular}{|c|c|c|c|}
\hline Variable Name & Odds Ratio & Marginal Effect ${ }^{a}$ & $z$-Value \\
\hline Saving energy is important & $\begin{array}{l}1.69 * \\
(0.52)\end{array}$ & 0.05 & 1.77 \\
\hline Purchased a washing machine & $\begin{array}{l}2.86^{*} \\
(1.78)\end{array}$ & 0.10 & 1.72 \\
\hline $\begin{array}{l}\text { Purchased new windows for apartment } \\
\text { or house }\end{array}$ & $\begin{array}{l}6.29 * * \\
(4.87)\end{array}$ & 0.18 & 2.48 \\
\hline Important that renewable energy is safe & $\begin{array}{c}0.88 \\
(0.53)\end{array}$ & -0.01 & -0.21 \\
\hline $\begin{array}{l}\text { Important that renewable energy is } \\
\text { reliably supplied without disruption }\end{array}$ & $\begin{array}{l}4.29 * * \\
(2.97)\end{array}$ & 0.14 & 2.18 \\
\hline $\begin{array}{l}\text { Important that renewable energy is } \\
\text { cheaper than conventional }\end{array}$ & $\begin{array}{r}0.55 \\
(0.28)\end{array}$ & -0.06 & -1.17 \\
\hline $\begin{array}{l}\text { Think that own health is affected by air } \\
\text { pollution }\end{array}$ & $\begin{array}{l}4.06^{* *} \\
(2.52)\end{array}$ & 0.14 & 2.33 \\
\hline $\begin{array}{l}\text { Think that own health is affected by soil } \\
\text { pollution }\end{array}$ & $\begin{array}{l}3.20 * \\
(2.03)\end{array}$ & 0.11 & 1.90 \\
\hline $\begin{array}{l}\text { Think that own health is affected by } \\
\text { water pollution }\end{array}$ & $\begin{array}{c}0.38 \\
(0.26)\end{array}$ & -0.09 & -1.43 \\
\hline Gender & $\begin{array}{c}2.94^{* *} \\
(1.54)\end{array}$ & 0.10 & 2.13 \\
\hline Marital status & $\begin{array}{c}4.49 * * * \\
(2.59)\end{array}$ & 0.15 & 2.73 \\
\hline Number of household members & $\begin{array}{l}0.61 * \\
(0.17)\end{array}$ & -0.05 & -1.77 \\
\hline $\begin{array}{l}\text { Dummy for education above high } \\
\text { school }\end{array}$ & $\begin{array}{l}3.08 * \\
(1.83)\end{array}$ & 0.11 & 1.95 \\
\hline Monthly income & $\begin{array}{l}1.59 \text { ** } \\
(0.32)\end{array}$ & 0.04 & 2.38 \\
\hline Farmer & $\begin{array}{l}2.77 * \\
(1.71)\end{array}$ & 0.10 & 1.69 \\
\hline Constant & $\begin{array}{r}1.6 \times 10^{-7} \\
\left(4.7 \times 10^{-7}\right)\end{array}$ & - & - \\
\hline $\begin{array}{l}\text { Number of observations } \\
\text { Correctly classified } \\
\text { Chi-squared } \\
\text { Log likelihood } \\
\text { Pseudo } R^{2} \\
\text { McFadden } \\
\text { Tjur's R-square }\end{array}$ & $\begin{array}{c}194 \\
89.18 \% \\
89.28 \\
-61.62 \\
0.42 \\
0.42 \\
0.47\end{array}$ & & \\
\hline
\end{tabular}

Note: The standard errors in are parentheses. ${ }^{* * *} p<0.01,{ }^{* *} p<0.05$, and ${ }^{*} p<0.1$; ${ }^{\text {a }}$ the effect in the case of a binary variable. 
A positive relationship of the perceived importance of renewable energy is also established if a respondent believes that health is linked to air or soil pollution and with the attached importance to a reliable, uninterrupted supply of renewable energy. The probability of viewing renewable energy as important increases by $14 \%$ if a respondent links health to air pollution and by $11 \%$ if the respondent links health to soil pollution. If it is important that renewable energy is reliably supplied without disruption, the probability of viewing renewable energy as important increases by $14 \%$. Among proxies measuring respondent behavior consistent with energy-saving attitudes, the positive effect on the importance of renewable energy is confirmed if a respondent believes that saving energy is important (a $5 \%$ probability increase) or replaced residential windows or a washing machine in the 12 months preceding the survey (an 18\% and 10\% probability increase, respectively).

To sum up, the effects of explanatory variables on the perceived importance of renewable energy originate from three groups of factors (Figure $1 \mathrm{a}-\mathrm{h}$ ). The three groups include views and demonstrated behaviors consistent with reducing the use of energy in a household, recognition of the link between various types of environmental pollution and personal health, and sociodemographic and economic characteristics of the respondent. In the case of the first group of factors, the important finding is between the recent choice of the respondent to make the household and the house more energy-efficient with the purchase of a washing machine or the replacement of windows and the increasing importance attached to renewable energy. The estimated results show that respondents who indicated that saving energy was important would agree that renewable energy was important with the probability of about 0.8 (as the value of saving energy increases-i.e., becomes more important- the probability of attaching importance to renewable energy also increases from a probability of 0.53 to a probability of 0.80) (Figure 1a). Whereas the purchase of a new washing machine, a frequently used home appliance, increases the probability to a meaningful 0.78 , replacing old windows with new ones had an even greater effect (Figure 1b,c). This result is very encouraging, imply that energy-saving actions coincide with a substantial increase in the probability of perceiving the importance of renewable energy. At the time of the survey, $28 \%$ of buildings had modern quality windows [54].

The surveyed rural residents expect renewable energy to be reliably supplied, since rural areas experience longer periods of blackouts if weather events and broken power lines disrupt the energy supply. The increasing importance of renewable energy in this context likely accounts for the belief that the local generation of electric power can increase village independence from the malfunction of the grid. Those who considered the uninterrupted supply of renewable energy as important also recognized the importance of renewable energy as a whole with an increase from a probability of 0.08 to a probability of 0.83 (Figure 1d). The reliability of energy supply was identified as a barrier in the diffusion of renewable energy technologies $[55,56]$.

The importance of air pollution and its effect on personal health had a relatively larger probability of increasing the view that renewable energy was important than the perception of soil pollution's influence on health. Ferreira et al. [57] found a significant relationship between air pollution and self-reported individual subjective well-being. The findings were consistent with the result of the current study since rural households largely depend on coal for heating and coal burning releases smoke and soot into the atmosphere. About three quarters of rural households use coal as compared to about one in four urban households [49]. The model predictions support the high effect of concern about air pollution. The probability of agreeing that renewable energy is important rapidly increases from about 0.12 to 0.87 if a respondent attached importance to the effect of air pollution on health and from about 0.20 to about 0.85 when a respondent linked soil pollution with personal health (Figure 1e,f). 


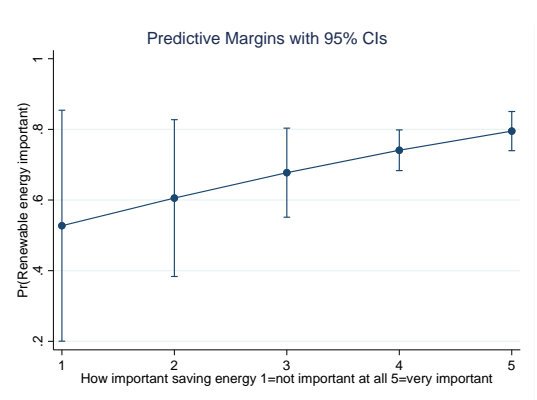

(a)

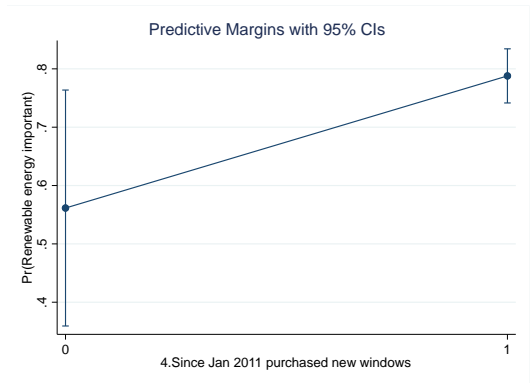

(c)

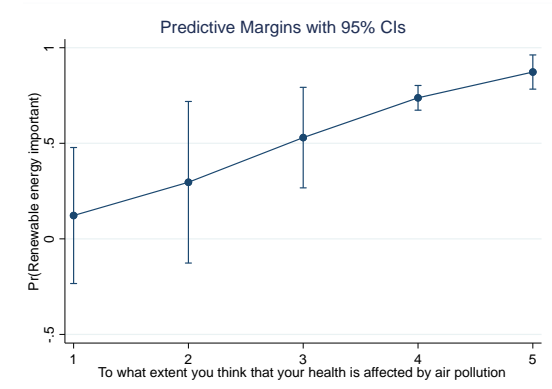

(e)

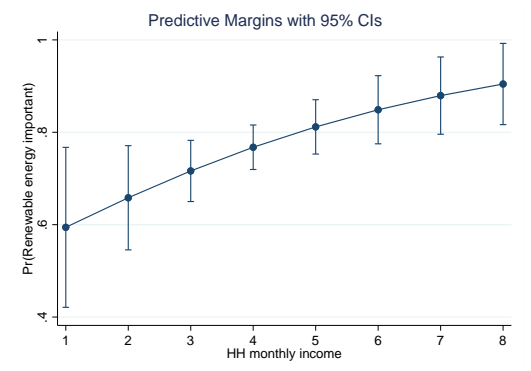

(g)

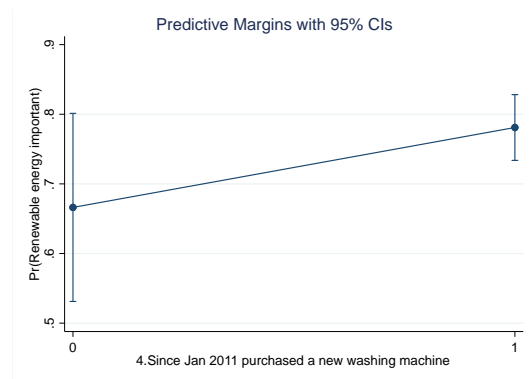

(b)

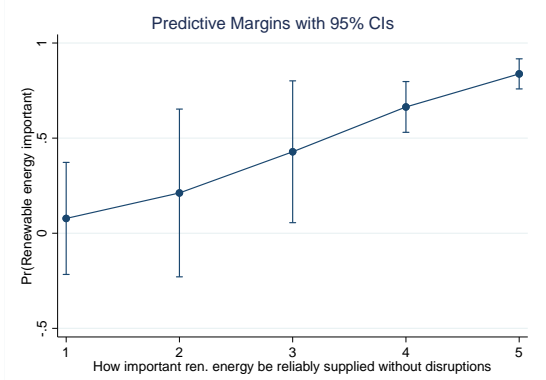

(d)

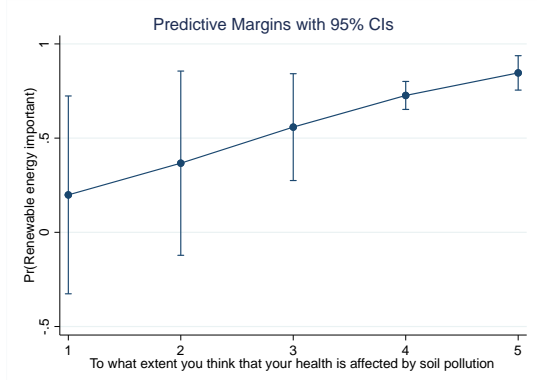

(f)

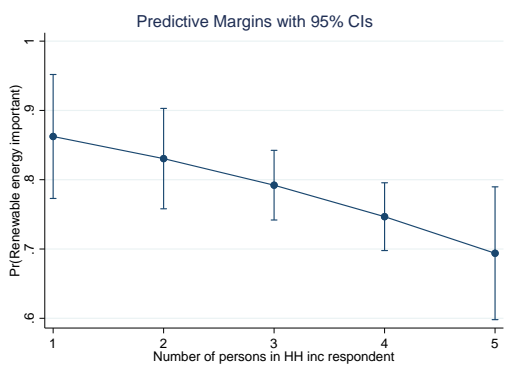

(h)

Figure 1. The predictions of the probability changes in independent variables including importance attached to energy savings (a), purchase of new energy-efficient washing machine (b) and windows (c), importance of reliable supply of renewable energy (d), perception of air (e) and soil (f) pollution effect on health, income (g) and household size (h), and their effect on the dependent variable or agreeing that renewable energy is important (The predictive margins have $95 \%$ confidence intervals).

Income has a modest effect on the probability of agreeing that renewable energy is important if the change involves a shift from a lower to the adjacent higher income category. A shift by one category is realistic because wage increases from year to year are generally much less than the range of an income category applied in the survey. However, Figure $1 \mathrm{~g}$ shows that the increase in the probability 
of agreeing that renewable energy is important along the eight income categories is substantial, and for respondents in the highest category, the probability is about 0.90 .

The only feature that led to a decrease in the probability of perceiving renewable energy as important was in the group of sociodemographic variables. Each additional household member lowered the probability by $5 \%$. However, as shown on Figure $1 \mathrm{~h}$, since the probability that a single person household would agree that the importance of renewable energy is quite high (more than 0.85 ), even for a five-person household, the probability is still predicted at about 0.70 . The substantial effect of education and gender is consistent with earlier studies. The strong effect of marital status is plausible. A family is likely to discuss various current issues, including renewable energy importance, a probable topic of school assignments brought home by children.

\section{Conclusions}

Renewable energy utilization increases as a result of improved energy-generating equipment, growing demands for energy, and concerns regarding the effects of using fossil fuels. Modern technology allows the scaling of renewable energy-generating equipment to a size that allows installation by households, for example, passive or photovoltaic solar panels, local entrepreneurs converting old grain mills into small hydroelectric power plants on even small rivers in rural Poland, or farmers allowing for the construction of windmills on their land.

The key factor influencing renewable energy generation and use is the acceptance of local residents. To educate the public about renewable energy attributes that enhance the local economy and quality of life, it is necessary to investigate the link between specific factors and attitudes.

This study uses survey data to examine the perception of renewable energy importance among rural residents in eastern Poland. The results of the empirical analysis show that the sociodemographic and economic characteristics of residents, the perceptions of links between health and specific sources of environmental pollution, and the actions demonstrating energy saving behavior are important factors for this perception. Rural residents in the surveyed villages attached importance to renewable energy at a relatively higher income and education levels. Accordingly, it appears that efforts promoting renewable energy should focus on families, which can be reached through rural schools and local civic groups. Our results also show that actions consistent with the desire to conserve energy and its cost by utilizing energy-efficient household appliances, reducing household heat loss, and favoring renewable energy can be encouraged by commercial entities manufacturing, distributing, and installing related equipment. A very important result from the standpoint of promoting the importance of renewable energy use is the confirmed positive association between the opinion linking personal health with air and soil pollution and an individual's view of renewable energy. The importance of health is universally recognized, and understanding that environmental factors can have a detrimental effect is a potentially powerful argument in encouraging the local development and utilization of renewable energy. Since the health care system is run by the government, relevant agencies should incorporate the message about environment quality into their health maintenance and prevention program.

Author Contributions: A.U. contributed to the preparation of the survey working with W.J.F. and implemented the survey. A.M.K. contributed to the preparation of the survey and literature search and review. O.K. and W.J.F. conducted the economic analysis, reviewed the related literature and wrote the paper. All of the authors approved the publication.

Funding: This research did not receive external funding.

Conflicts of Interest: Authors declare no conflict of interest. 


\section{References}

1. Dziennik Urzędowy. Dyrektywa Parlamentu Europejskiego i Rady 2009/28/WE z dnia 23 kwietnia 2009 r. w sprawie promowania stosowania energii ze źródeł odnawialnych zmieniająca i w następstwie uchylająca dyrektywy 2001/77/WE oraz 2003/30/WE. 2009. Available online: http:/ / eur-lex.europa.eu/legalcontent/ PL/TXT/?uri=uriserv:OJ.L_.2009.140.01.0016.01.POL\&toc=OJ:L:2009:140:TOC (accessed on 15 May 2017).

2. European Commission (2018a) Effort Sharing: Member States' Emission Targets. Available online: https: / / ec.europa.eu/clima/policies / effort_en (accessed on 25 October 2018).

3. European Court of Auditors, Renewable Energy for Sustainable Rural Development: Significant Potential Synergies, But Mostly Unrealised, Report 05/2018. Available online: http://publications.europa.eu/ webpub/eca/special-reports/renevable-energy-5-2018/ro/\#figure1 (accessed on 28 March 2019).

4. OECD. Linking Renewable Energy to Rural Development; OECD: Paris, France, 2012.

5. Nęcka, K. Analysis if the continuity of electric energy supply in Poland. Teka Kom. Mot. i Energ. Roln. 2011, 11, 230-236.

6. Radio Poland. Power Outages Costing Polish Economy Millions. 2015. Available online: http:// www.thenews.pl/1/12/Artykul/198267, Power-outages-costing-Polish-economy-millions (accessed on 10 October 2018).

7. Jędrak, J.; Konduracka, E.; Badyda, A.J.; Dąbrowiecki, P. Wpływ zanieczyszczeń powietrza na zdrowie; Polskiego Towarzystwa Medycyny Środowiskowej, Wojskowego Instytutu Medycznego, Polskiej Federacji Stowarzyszeń Chorych na Astmę, Alergię i POChP: Krakow, Poland, 2017; ISBN 978-83-943065-0-2.

8. IEA (International Energy Agency). Key Trends in CO2 Emissions, Excerpt from: CO2 Emissions from Fuel Combustion; OECD/IEA: Paris, France, 2015; Available online: http://www.iea.org/publications/ freepublications/publication/CO2EmissionsTrends.pdf (accessed on 26 February 2019).

9. Klepacka, A.M.; Pieńczuk, E.; Kamińska, N. The Use of Solar Energy in the Opinion of County Employees in Mazowieckie Voivodship. In Proceedings of the 15th International Scientific Days. Challenges and Prospects for Innovation between 2014-2020, Gyöngyös, Hungary, 30-31 March 2016. Electronic document: 869-876.

10. Woźniak, E. Występowanie biogazowni rolniczych w Polsce i czynniki ich lokalizacji. In Interdyscplinarne zagadnienia w inżynierii i ochronie środowiska; Kaźmierczak, B., Kotowski, A., Piekarska, K., Eds.; Politechnika Wrocławska: Wrocław, Poland, 2016; pp. 334-344.

11. Zerrahn, A. Wind Power and Externalities. Ecol. Econ. 2017, 141, 245-260. Available online: https: / /www. sciencedirect.com/science/article/pii/S0921800915305255 (accessed on 18 January 2019). [CrossRef]

12. Bergmann, A.; Colombo, S.; Hanley, N. Rural versus urban preferences for renewable energy developments. Ecol. Econ. 2008, 65, 616-625. Available online: https://www.sciencedirect.com/science/article/pii/ S0921800907004387?via\%3Dihub (accessed on 18 January 2019). [CrossRef]

13. Bidwell, D. The role of values in public beliefs and attitudes towards commercial wind energy. Energy Policy 2013, 58, 189-199. [CrossRef]

14. Portalsamorzadowy.pl. PKB na mieszkańca w województwach. Mazowsze przoduje, kto najbardziej w tyle? Available online: http://www.portalsamorzadowy.pl/prawo-i-finanse/pkb-na-mieszkanca-wwojewodztwach-mazowsze-przoduje-kto-najbardziej-w-tyle,88476.html (accessed on 8 February 2018).

15. Giatrakos, G.P.; Tsoutsos, T.D.; Zografakis, N. Sustainable power planning for the island of Crete. Energy Policy 2009, 37, 1222-1238. [CrossRef]

16. Eurobarometer. Climate Change, Special Eurobarometer 409; European Commission: Brussels, Belgium, 2014; Available online: http:/ / ec.europa.eu/public_opinion/archives/ebs/ebs_409_en.pdf (accessed on 14 June 2018).

17. Agentur für Erneuerbare Energien (German Agency for Renewable Energies). Renews Kompakt. Opinions on Renewables-A Look at Polls in Industrialised Countries. Nr. 29. March 2016. Available online: https://www.unendlich-viel-energie.de/media/file/427.AEE_RK29_Internationale_ Akzeptanzumfragen_EN.pdf (accessed on 18 June 2019).

18. Mroczek, B. Akceptacja doroslych Polaków dla energetyki wiatrowej i innych odnawialynch źródeł energii. Streszczenie raportu; Pomorski Uniwersytet Medyczny w Szczecinie, Zakład Publiczengo: Szczecin, Poland, 2011; Available online: http://domrel.pl/_publikacje/raport_akceptacja.pdf (accessed on 21 May 2018).

19. Wojciechowska-solis, J.; Soroka, A. Attitude of the Polish society towards renewable energy sources. Segmentation by gender. Intercathedra 2018, 1, 87-93. 
20. Energy and Climate Change Public Attitudes Tracker: Wave 25. 2018. Available online: https:/ /assets.publishing.service.gov.uk/government/uploads/system/uploads/attachment_data/ file/702640/Wave_25_Summary_Report.pdf (accessed on 18 June 2018).

21. Risk Dialogue Foundation St. Gallen (Foundation Risiko-Dialog St. Gallen). Die Stromzukunft der Schweiz: Erwartungen der Bevölkerung und Präferenzen bei Zielkonflikten, November 2015. Available online: https:/ $/$ www.google.com/url?sa=t\&rct=j\&q=\&esrc=s\&source=web\&cd=1\&ved= 2ahUKEwjOzNOCmLnhAhWJ3KQKHQPpAIwQFjAAegQIARAC\&url=https\%3A\%2F\%2Fwww. aeesuisse.ch $\% 2 F d e \% 2 F$ publikationen $\% 2$ Fstudien $\% 3$ Ffile $\% 3$ Dfiles $\% 2$ Fuser $\% 2 F p a g e s \% 2 F d e \% 2 F a e e \%$ 2Fpublikationen\%2Fstudien\%2FStiftung\%2520Risiko\%2520Dialog_Die\%2520Stromzukunft\%2520der\% 2520Schweiz_20160314.pdf\&usg=AOvVaw1HCzUXfSOUUJBvGPT26zPp (accessed on 25 June 2018).

22. SolarCity. US Homeowners on Clean Energy: A National Survey. Available online: http:/ /www.solarcity.com/ sites/default/files/reports/reports-2015-homeowner-survey-clean-energy.pdf (accessed on 25 June 2018).

23. Gallup: Energy, Suravey on Topics Related to Energy. 2015. Available online: http://news.gallup.com/poll/ 2167/energy.aspx (accessed on 20 June 2018).

24. Walter, G. Determining the local acceptance of wind energy projects in Switzerland: The importance of general attitudes and project characteristics. Energy Res. Soc. Sci. 2014, 4, 78-88. [CrossRef]

25. Eiser, J.R.; Aluchna, K.; Jones, C.R. Local wind or Russian gas? Contextual influences on Polish attitudes to wind energy development. Environ. Plan. C 2010, 28, 590-608. [CrossRef]

26. Gielnik, A.; Rosicki, R. Energetyka wiatrowa w Polsce-Możliwości rozwoju i zagrożenia. 2013. Available online: https: / / repozytorium.amu.edu.pl/handle/10593/6064 (accessed on 21 February 2019).

27. Mroczek, B.; Kurpas, D. Social attitudes towards wind farms and other renewable energy sources in Poland. Medycyna Środowiskowa-Environ. Med. 2014, 4, 19-28.

28. Kowalczyk-Juśko, A.; Kościk, B. Assessment of the ecological and energy awareness of the citizens in rural communes. Barom. Reg. 2015, 13, 161-168.

29. Dmochowska-Dudek, K.; Bednarek-Szczepańska, M. A profile of the Polish rural NIMBYist. J. Rural Stud. 2018, 58, 52-66. [CrossRef]

30. Borges Neto, M.R.; Carvalho, P.C.M.; Carioca, J.O.B.; Canafistula, F.J.F. Biogas / photovoltaic hybrid power system for decentralized energy supply of rural areas. Energy Policy 2010, 38, 4497-4506. [CrossRef]

31. Bajpai, P.; Dash, V. Hybrid renewable energy systems for power generation in stand-alone applications: A review. Renew. Sustain. Energy Rev. 2012, 16, 2926-2939. [CrossRef]

32. Rahman, M.; Hasan, M.M.; Paatero, J.V.; Lahdelma, R. Hybrid application of biogas and solar resources to fulfil household energy needs: A potentially viable option in rural areas of developing countries. Renew. Energy 2014, 68, 35-45. [CrossRef]

33. Dziennik Ustaw 1276. Ustawa z dnia 7 czerwca 2018 r. o zmianie ustawy o odnawialnych źródłach energii oraz niektórych innych ustaw (2018). Available online: http:/ / www.dziennikustaw.gov.pl/DU/2018/1276 (accessed on 31 October 2018).

34. Florkowski, W.J.; Us, A.; Klepacka, A.M. Food waste and rural households support for local biogas production in Lubelskie Voivodship (Poland). Resour. Conserv. Recycl. 2018, 136, 46-52. [CrossRef]

35. Klepacka, A.M.; Florkowski, W.J.; Meng, T. Clean, accessible, and cost-saving: Reasons for rural household investment in solar panels in Poland. Resour. Conserv. Recycl. 2018, 139, 338-350. [CrossRef]

36. Devine-Wright, P. Reconsidering public acceptance of renewable energy technologies: A critical review. In Delivering a Low Carbon Electricity System: Technologies, Economics and Policy; Jamasb, T., Grubb, M., Pollitt, M., Eds.; Department of Applied Economics Occasional Papers (No. 68); Cambridge University Press: Cambridge, UK, 2008.

37. Ekins, P. Step changes for decarbonising the energy system: Research needs for renewables, energy efficiency and nuclear power. Energy Policy 2004, 32, 1891-1904. [CrossRef]

38. Wüstenhagen, R.; Wolsink, M.; Burer, M.J. Social acceptance of renewavble energy innovation: An introduction to the concept. Energy Policy 2007, 35, 2683-2691. [CrossRef]

39. Miranda, G.; Eberts, R.W.; González, E.; Foo, V.; Kulawczuk, P. Climate Change, Employment and Local Development in Poland; OECD Local Economic and Employment Development (LEED) Working Papers, 2011/22; OECD Publishing: Paris, France, 2011.

40. Wooldridge, J.M. Introductory Econometrics: A Modern Approach, 6th ed.; Cengae Learning: Boston, MA, USA, 2015. 
41. Stock, J.H.; Watson, M.W. Introduction to Econometrics, 3rd ed.; Pearson: London, UK, 2014.

42. Greene, W.H. Econometric Analysis, 6th ed.; Pearson: Upper Saddle River, NJ, USA, 2008.

43. Allison, P. What's the Best R-Squared for Logistic Regression? 2013. Available online: http:// statisticalhorizons.com/r2logistic (accessed on 18 January 2019).

44. Introduction to Stata. UCLA: Statistical Consulting Group. 2018. Available online: https://stats.idre.ucla. edu/other/mult-pkg/faq/general/faq-what-are-pseudo-r-squareds / (accessed on 25 March 2019).

45. Freese, J.; Long, J.S. Regression Models for Categorical Dependent Variables Using Stata; Stata Press: College Station, TX, USA, 2006.

46. Tjur, T. Coefficients of determination in logistic regression models-A new proposal: The coefficient of discrimination. Am. Stat. 2009, 63, 366-372. [CrossRef]

47. GUS (Główny Urząd Statystyczny). Budżety Gospodarstw Domowych: W 2008 R. Household Budget Survey in 2008; GUS (Główny Urząd Statystyczny): Warszawa, Poland, 2009; p. 190. (In Polish)

48. GUS (Główny Urząd Statystyczny). Budżety Gospodarstw Domowych: W 2013 R. Household Budget survey in 2013; GUS (Główny Urząd Statystyczny): Warszawa, Poland, 2014; p. 237. (In Polish)

49. GUS (Główny Urząd Statystyczny). Energy Consumption in Households in 2015; GUS (Główny Urząd Statystyczny): Warszawa, Poland, 2017; p. 166. (In Polish)

50. Polednik, B. Particulate matter and student exposure in school classrooms in Lublin, Poland. Environ. Res. 2013, 120, 134-139. [CrossRef]

51. Zielonka, U.; Hlawiczka, S.; Fudala, J.; Wängberg, I.; Munthe, J. Seasonal mercury concentrations measured in rural air in southern Poland contribution from local and regional coal combustion. Atmos. Environ. 2005, $39,7580-7586$.

52. Kozyra, I.; Kaupke, A.; Rzeżutka, A. Seasonal occurrence of human enteric viruses in river water samples collected from rural areas of south-east Poland. Food Environ. Virol. 2011, 3, 115-120. [CrossRef]

53. X-Rates. Available online: http:/ / www.X-rates.com/historical / ?from=PLN\&amount=1\&date=2015-07-01 (accessed on 9 February 2018).

54. Przeglą 2013; Instytut Ekonomii Srodowiska: Kraków, Poland, 2014.

55. Reddy, S.; Painuly, J.P. Diffusion of renewable energy technologies-Barriers and stakeholders' perspectives. Renew. Energy 2004, 29, 1431-1447. [CrossRef]

56. Eleftheriadis, I.M.; Anagnostopoulou, E.G. Identifying barriers in the diffusion of renewable energy sources. Energy Policy 2015, 80, 153-164. [CrossRef]

57. Ferreira, S.; Akay, A.; Brereton, F.; Cunado, J.; Martinsson, P.; Moro, M.; Ningal, T.F. Life satisfaction and air quality in Europe. Ecol. Econ. 2013, 88, 1-10. [CrossRef] 